\title{
Prerequisites for the development of a clear social responsibility concept
}

\author{
Andrii Yevstakhevych', Iren Karen Von-Nahy²
}

Received: 2021-03-12

Accepted: 2021-04-14

DOI: http://doi.org/10.46489/gpj.2021-1-1-5

\begin{abstract}
The concept of social responsibility has a broad interpretation due to different approaches to forming its concept, the definition of fundamental principles, methods, and ways to ensure the expected results. The term "social responsibility" should be used considering the current state of research in this area and the discourse formed under the influence of the integration of foreign experience in ensuring social responsibility and the practice of Ukrainian enterprises in this area. We considered the history of formation and development of the concept of social responsibility of enterprises in Ukraine. We noted that the approaches to the formation of the concept of social responsibility differ significantly. We emphasized that the development of a transparent concept of social responsibility should be based on the factors, content and models of this activity. We concluded that due to the crisis in the economy and society in Ukraine, the concept of social responsibility had acquired a unique regional shape. This gave rise to the lack of a unified state policy of social responsibility of business, unsystematic measures of enterprises to implement the introductory provisions, the lack of a systematic approach to the transformation of social responsibility management.
\end{abstract}

Keywords: social responsibility, theory of social responsibility, standards of social responsibility, factors of social responsibility.

\footnotetext{
${ }^{1}$ Andrii Yevstakhevych, PhD, lecturer, Department of Business Economics and Information Technology, Lviv university of business and law, Kulparkivska, 99, 79021 Lviv, Ukraine, e-mail: yevstakhevych10@meta.ua, ORCID: https://orcid.org/0000-0003-1058-5359

${ }^{2}$ Iren Karen Von-Nahy, lecturer, Department of Business Economics and Information Technology, Lviv university of business and law, Kulparkivska, 99, 79021 Lviv, Ukraine, ORCID: https://orcid.org/0000-0002-2748-7766
} 


\section{ВСТУП}

У зв'язку 3 об'єктивними чинниками, що виникають як наслідок переходу до ринкової економіки, інтереси підприємств та держави, громад, громадян вимагають узгодження. Після здобуття незалежності, Україна поступово трансформувалась у соціальноорієнтовану державу 3 ринковою економікою. Утім, перманентні кризові явища в економіці та соціальній сфері спровокували загострення конфлікту між інтересами підприємств, держави і суспільства. У короткостроковому вимірі, намагаючись максимізувати прибутки підприємства нерідко стали діяти всупереч інтересам держави (наприклад, виходячи у тіньовий сектор економіки, завдаючи своїми діями шкоди екологічній ситуації тощо), ще частіше - суспільства (порушуючи зобов'язання перед працівниками, ігноруючи вимоги громадськості щодо своєї діяльності, завдаючи інших прямих чи непрямих збитків оточуючому середовищу тощо). $\mathrm{y}$ довгостроковому вимірі така стратегія діяльності підприємств не може вважатись продуктивною, оскільки суперечить основоположному діалектичному принципу взаємозв'язку та взаємообумовленості. Вирішенням цієї проблеми $\epsilon$ реалізація концепції соціальної відповідальності підприємств, що пройшла тривалий шлях розвитку та широко апробована у розвинених країнах.

Концепція

відповідальності розвивалась протягом тривалого часу. На сьогоднішній день виокремилось досить багато теоретичних підходів до розуміння соціальної відповідальності. Питанням соціальної відповідальності присвячено, праці таких вчених, як Баюра Д., Брич В. Я., Головінов О. М., Градюк Н. М., Дєліні М. М., Колот А. М., Лазоренко Л. В., Марущак Н. В.,
Селіверстова Л., Стойка В. О., Чала Ю. В. та ін.

Доповнюючи результати, одержані згаданими авторами, у даному дослідженні маємо на меті з'ясувати актуальний стан розвитку концепції соціальної відповідальності для вітчизняних реалій.

Відтак, метою статті є виявлення особливостей сучасного трактування концепції соціальної відповідальності підприємств в Україні.

\section{РЕЗУЛЬТАТИ}

Поняття соціальної відповідальності має широке тлумачення, що обумовлюється різними підходами до формування їі концепції, визначення основних принципів, методів та шляхів забезпечення, очікуваних результатів. Оперувати терміном «соціальна відповідальність» слід 3 урахуванням актуального стану досліджень у цій сфері та дискурсу, сформованого під впливом інтеграції іноземного досвіду забезпечення соціальної відповідальності та практики українських підприємств у цій сфері.

Досліджуючи проблематику соціальної відповідальності, Ю.В. Чала (2014) зазначає, що основою ефективної ринкової економіки та демократичного суспільства $є$ безперервний діалог між урядом, бізнесом і громадським суспільством. Соціальна відповідальність бізнесу $\epsilon$ одним із ключових факторів для побудови такого діалогу. Ступінь розвитку соціальної відповідальності бізнесу відображає рівень партнерства між компаніями, урядовими структурами та головними дійовими особами громадянського суспільства щодо вирішення соціальних проблем i прискоренню розвитку суспільства. Брич В.Я. та Смачило I. I. (2014) наголошують, що економіка України на сучасному етапі характеризується трансформаційними процесами, через перебіг яких постійно змінюються умови функціонування 
підприємств. Цілеспрямований та безперервний розвиток підприємств, який підтримує рівень економічних, виробничих, технічних, соціальних показників у межах, визначених впливом зовнішнього та внутрішнього середовищ, потребує врахування інтересів споживачів, підлеглих, суспільства, партнерів, працівників, постачальників, менеджерів, акціонерів. Тому соціальна відповідальність $\epsilon$ стратегічним напрямком соціального розвитку підприємств. На думку Лазоренко Л. В. (2013), соціальна відповідальність підприємств у сучасних умовах $\epsilon$ невід'ємною складовою їх ефективної діяльності. Соціально відповідальні організації здійснюють вагомий внесок в розвиток суспільства, адже на власному прикладі демонструють ставлення до свого персоналу, навколишнього середовища, результатів своєї діяльності та країни в цілому. 3 іншого боку, висока корпоративна культура та відповідальність підприємств сприяє підвищенню їх фінансових можливостей, тому що такі організації мають досить високу репутацію як в Україні, так i за кордоном, що $\epsilon$ причиною успішного ведення бізнесу, підвищення конкурентоспроможності та економічної ефективності завдяки забезпеченню належної уваги до інтересів споживачів, клієнтів, партнерів і навіть конкурентів; запровадження правил раціонального менеджменту та належного контролю.

Щодо зародження концепції соціальної відповідальності бізнесу Н. В. Марущак (2012) виокремлює низку етапів. Теоретичне підгрунтя концепції соціальної відповідальності бізнесу було закладене ще у XVIII ст., коли відбувалися індустріальні революції та формувалося сучасне уявлення про підприємництво. Власники окремих підприємств брали на себе відповідальність за своїх працівників, керуючись при цьому власними релігійними чи етичними переконаннями. На початку XX ст., відзначає науковець, у США зароджується доктрина капіталістичної благодійності, згідно якої прибуткові організації повинні жертвувати частиною своїх коштів на користь суспільства, тобто фінансувати суспільні потреби. Подальшого розвитку концепція соціальної відповідальності набула лише у 50-ті роки XX століття, зайнявши центральне місце у дискусії про відносини бізнесу та суспільства.

По іншому трактує еволюцію концепції соціальної відповідальності А. Колот (2013), котрий зауважує, що реакцією на потребу розбудови успішних прикладних систем соціально відповідальної діяльності стала поява в цій царині цілої низки концепцій, які містять результати наукового опрацювання питань соціальної відповідальності бізнес-структур. Наукова думка з цієї проблематики, на думку науковця, сконцентрована у таких концепціях: базова концепція (1950-1970-і роки); концепція корпоративної соціальної сприйнятливості (1970-1990-і роки); концепція корпоративної соціальної діяльності (1980-2000-і роки).

Безперечно, можливо виводити концептуальні засади соціальної відповідальності бізнесу від найдавніших часів, адже підприємництво та суспільство нерозривно пов'язані у своєму розвитку. Утім, вважаємо за доцільне користуватись хронологічними рамками розвитку концепції соціальної відповідальності, запропонованими у аналізованих працях, оскільки вони прив'язуються до основних етапів розвитку наукової думки 3 проблем менеджменту підприємств.

Слід зауважити, що окремі дослідники намагаються простежити більш давні свідчення зародження концепції соціальної відповідальності 
підприємств, утім ми погоджуємось 3 позицією Дєліні М. М. (2014), згідно з якою ця концепція зароджувалася як категорія регулювання соціальнотрудових відносин та отримала розвиток у вигляді благодійності спочатку американських багатіїв, а згодом й американських корпорацій. Науковець зазначає, що нині кількість форм їі прояву більш численна: це й захист навколишнього середовища, й впровадження новітніх засобів виробництва та управління, й всебічний соціальний захист працівника тощо.

Звичайно, у світлі відсутності єдиного підходу до побудови системи менеджменту соціальної відповідальності підприємств можливо виокремити незліченну кількість напрямків. Слід відзначити, водночас, що соціальна відповідальність як різновид управлінської діяльності $\epsilon$ досить складним явищем, що характеризується, передусім у вимірі витрат та часу i не передбачає однозначних здобутків для підприємства, що надає схожості цьому виду діяльності з благочинністю.

Утім, Брич В.Я. та Смачило I. I. (2014) звертають увагу на переваги, які надає для підприємства реалізація соціальної відповідальності: підвищення інвестиційної привабливості, збільшення обсягів продажу та прибутків, поліпшення процесів прийняття рішень та управління ризиками, оптимізація операційних процесів та зменшення виробничих витрат, зростання продуктивності та якості, ефективна база людських ресурсів, покращення репутації, більша лояльність покупців, поліпшення фінансових та економічних показників діяльності та інші.

3 іншого боку, Л.С. Селіверстова (2015) зауважує, що, як правило, корпоративна соціальна відповідальність підтверджується тільки «мінімальним набором» - вчасно сплаченими податками, регулярною

виплатою дивідендів, наданням соціального пакету та окремими благодійними заходами та акціями. Але як показують різноманітні дослідження в сфері корпоративної соціальної відповідальності, для того, щоб відповідати достатньо високим вимогам суспільства, необхідно грунтуватися не на окремих соціальних заходах, а цілеспрямовано вибудовувати комплексну політику підприємства в сфері корпоративної соціальної відповідальності.

Можливо виокремити й певний перелік чинників, котрі підштовхують до реалізації концепції соціальної відповідальності.

Д. Баюра (2009) до основних мотивів реалізації концепції соціальної відповідальності українськими підприємствами відносить такі, як розвиток персоналу компанії, що не лише запобігає плинності кадрів, але й дозволяє залучати кращих спеціалістів із ринку праці; потреба забезпечити зростання продуктивності праці в компанії; покращення іміджу компанії та зростання репутації; реклама товарів і послуг; висвітлення діяльності компанії в засобах масової інформації; стабільність і стійкий розвиток компанії в довгостроковій перспективі; можливість залучення інвестиційного капіталу для розвитку соціально-відповідальних компаній; збереження соціальної стабільності в суспільстві; в окремих країнах, в яких існують соціально відповідальні компанії, передбачені податкові пільги.

Важливим для соціальної відповідальності як загальносвітового руху $\epsilon$ стандартизація суміжних процесів.

$\begin{array}{lll}\text { Особливо значимим } & \text { здобутком } \\ \text { теорії та практики } & \text { соціальної } \\ \text { відповідальності та новим } & \text { етапом їх } \\ \text { розвитку слід вважати } & \text { прийнятTя } \\ \text { стандарту ISO 26000. Ю.В. Чала (2014) } \\ \text { зазначає, що цим } & \text { стандартом }\end{array}$


визначаються вказівки для керівництва про те, як підприємства та організації можуть працювати соціально відповідальним чином, що розуміють як дії в рамках етичних норм 3 метою внеску в здоров'я i благополуччя суспільства.

Щодо ситуації 3 реалізацією соціальної відповідальності в Україні, аналіз останніх досліджень засвідчує наступні закономірності.

Водночас, щодо ситуації в Україні 0 . М. Головінов (2014) зауважує, що для українських компаній соціальна відповідальність переважно носить разовий характер, спрямований на покращення репутації, без бажання (часто і можливості) розглядати даний процес як тривалий i безперервний, нарешті, відсутня конструктивна, взаємовигідна взаємодія роботодавців і найманих працівників. Розвиток цього процесу в Україні має численні бар'єри, часом як штучні, так i природні. У національному господарстві України певною мірою представлені всі рівні реалізації концепції соціальної відповідальності. У той же час існуючу систему соціальної відповідальності неможливо назвати гармонійною, оскільки багато її елементів не виникли в ході еволюційного розвитку ринкових відносин, а залишилися у спадок від радянської системи соціального забезпечення.

Соціальна відповідальність у зв'язку зі своєю значимістю у довгостроковому вимірі відноситься до сфери стратегічного управління підприємствами. Як зазначає Стойка B.0. (2014), у сучасних умовах господарювання соціальна відповідальність бізнесу $\epsilon$ складовою його корпоративної стратегії. 3 позиції юриспруденції, реалізація принципу соціальної відповідальності пов'язана 3 публічно-правовим регулюванням фондів грошових коштів комерційних організацій, тобто правове регулювання відносин щодо розподілу прибутку повинно забезпечувати використання частини прибутку комерційних організацій 3 метою здійснення соціальної функції і часткового фінансування програм із вирішення соціальних проблем суспільства.

Щодо заходів, які включаються до концепції соціальної відповідальності, погодимося $з$ Д. Баюрою (2009), котрий відзначає, що розвиток економіки України та системи корпоративного управління на основі відповідальності та якості зумовлює актуальність проблеми формування корпоративної соціальної відповідальності підприємств. 3 цього приводу, як зауважує науковець, ООН та міжнародне співтовариство вдаються до заходів, які спрямовані на розвиток партнерства між державою та бізнесом, роботодавцями та працівниками i грунтуються на правах людини. Проведений науковцем аналіз діяльності соціально-відповідальних компаній України засвідчив найбільш вираженість таких напрямів їх соціальної активності: підтримка соціально незахищених верств населення, розвиток соціальної інфраструктури, розвиток освіти, спонсорська допомога, молодіжні програми, надання медичних i рекреаційних послуг своїм працівникам тощо.

Щодо соціальної відповідальності підприємств перед територіальними громадами в Україні Н.М. Градюк (2011) відзначає, що більшість великих вітчизняних компаній вважає свою участь у розвитку територіальної громади складовою власної стратегії корпоративної соціальної відповідальності. Представники цих компаній позиціонують свою діяльність, спрямовану на вирішення тих чи інших соціальних проблем територіальної громади та суспільства, саме як вагому складову політики соціальної корпоративної відповідальності компанії. При цьому, наголошує 
науковець, мова не йде про те, що корпоративна благодійність $\epsilon$ повноцінним виявом соціальної відповідальності перед громадою. Навпаки, пов'язуючи ї̈ з власною місією, стратегією та ключовими компетенціями, компанії інтегрують благодійність та участь у життєдіяльності громади в загальні стратегії розвитку бізнесу, що охоплюють широке коло завдань та відповідальностей компанії.

Дєліні М. М. (2014) відзначає, що, у зв'язку 3 тим, що соціальна відповідальність бізнесу $\epsilon$ сьогодні загальновизнаним правилом, якого дотримується значна кількість великих, середніх і навіть малих підприємств різних країн світу, питання їі розвитку належать до сфери особливої уваги органів державної влади та провідних міжнародних організацій. Проявом цієї уваги, на думку Дєліні М. М. $\epsilon$ розроблення стандартів і заходів зі стимулювання організацій до соціально відповідальної діяльності. У більшості країн ЄС у різній формі розроблені та функціонують державні програми ㄲï підтримки і стимулювання. Такі інституційні заходи спрямовують бізнес на дотримання певних правил поведінки, заохочують державні та приватні організації до спільного виконання соціально важливих завдань, матеріально стимулюють бізнес до соціально відповідальної діяльності. На жаль, наголошує Дєліні М. М., формування інституційної підтримки соціальної відповідальності в Україні перебуває в стадії становлення. Автоматичне впровадження концепції соціальної відповідальності неможливе, тому, що надмірна «зарегульованість» економіки 3 боку держави у вигляді високих податків і соціальних трансфертів здатна привести до зниження мотивації до праці i інвестиційної активності, можливе переміщення виробничої діяльності 3 легальної області в нелегальну.

\section{ВИСНОВКИ}

Таким чином, на основі проведеного дослідження встановлено, що соціальна відповідальність $є \quad$ синтетичною категорією, що пройшла тривалий розвиток, доповнюючись новими елементами відповідно етапів розвитку теорії менеджменту. На сучасному етапі концепція соціальної відповідальності підприємств підтримується на міжнародному рівні ООН та урядами держав, поділяється найбільшими підприємствами і вважається однією 3 запорук сталого розвитку економіки. Водночас, в Україні концепція соціальної відповідальності набула особливих регіональних обрисів, що пов'язується 3 кризовими явищами в економіці та суспільстві. У підсумку це обумовило відсутність єдиної державної політики соціальної відповідальності бізнесу, несистемність заходів підприємств 3 реалізації основних положень, відсутність системного підходу щодо трансформації менеджменту соціальної відповідальності.

Перспективним напрямком подальших досліджень $\epsilon$ напрацювання принципів та методів менеджменту соціальної відповідальності підприємств.

\section{References}

Baiura, D. (2009). Korporatyvna sotsialna vidpovidalnist $\mathrm{u}$ systemi korporatyvnoho upravlinnia. Ukraina: aspekty pratsi, 1. 21-25

Brych, V., \& Ya. Smachylo, I. I. (2014). Sotsialna vidpovidalnist vitchyznianykh pidpryiemstv. Tekhnolohycheskyi audyt $y$ rezervы proyzvodstva, 5(2). 36-39

Chala, Yu. V. (2014). Sotsialna vidpovidalnist pidpryiemstv yak osnova innovatsiinoho rozvytku suchasnoi ekonomiky. Problemy $i$ perspektyvy rozvytku bankivskoi systemy Ukrainy, 40. 275-285 
Dielini, M. M. (2014). Problemy vprovadzhennia korporatyvnoi sotsialnoi vidpovidalnosti. Visnyk Odeskoho natsionalnoho universytetu. Seriia: Ekonomika. T. 19, Vyp. 2(5). 38-41.

Holovinov, O. M. (2014). Sotsialna vidpovidalnist biznesu: ukrainski realii i problemy. Ekonomichnyi visnyk Donbasu, 2. 187-192

Hradiuk, N. M. (2011). Sotsialna vidpovidalnist pidpryiemstv $\mathrm{v}$ umovakh stanovlennia hromadianskoho suspilstva $\mathrm{v}$ Ukraini. Rehionalna ekonomika, 2. 143-150

Kolot, A. M. (2013). Korporatyvna sotsialna vidpovidalnist: evoliutsiia ta rozvytok teoretychnykh pohliadiv. Ekonomichna teoriia, 4. 5-26
Lazorenko, L. V. (2013). Korporatyvna sotsialna vidpovidalnist yak innovatsiina stratehiia biznesu. Visnyk Skhidnoievropeiskoho universytetu ekonomiky i menedzhmentu. Ser.: Ekonomika i menedzhment, 1. 89-96

Marushchak, N. V. (2012). Evoliutsiia kontseptsii korporatyvnoi sotsialnoi vidpovidalnosti. Yevropeiski perspektyvy, 2(1). 213-221

Seliverstova, L. (2015). Formuvannia stratehii korporatyvnoi sotsialnoi vidpovidalnosti. Aktualni problemy ekonomiky, 7. 309-314

Stoika, V. O. (2014). Sotsialna vidpovidalnist biznesu - vazhlyva skladova ahroprodovolchoho rynku. Ekonomika kharchovoi promyslovosti, 4. 79-84 